\title{
Chronic liver disease prevention strategies and liver transplantation ${ }^{1}$
}

\author{
Estratégias de prevenção da doença hepática crônica e transplante de fígado
}

\author{
Anderson Soares da Silva ${ }^{2}$, Luciane Loures dos Santos ${ }^{2}$, Afonso Dinis Costa Passos ${ }^{3}$, Ajith Kumar Sankarankutty ${ }^{4}$, Ana \\ de Lourdes Candolo Martinelli ${ }^{5}$ Orlando de Castro e Silva ${ }^{6}$
}

1. Work performed in the Social Medicine Department and Liver Transplantation Unit of Division of Gastroenterology of the Department of Surgery and Anatomy - Faculty of Medicine of Ribeirão Preto - University of São Paulo (FMRP-USP), Brazil.

2. Fellow PhD degree of the Department of Social Medicine, (FMRP-USP), Brazil.

3. Full Professor of the Department of Social Medicine, (FMRP-USP), Brazil.

4. PhD, Professor of Division of Gastroenterology of the Department of Surgery and Anatomy, (FMRP-USP), Brazil.

5. PhD, Professor of the Department of Medicine, (FMRP-USP), Brazil.

6. Full Professor, Head of Division of Gastroenterology of the Department of Surgery and Anatomy, Coordinator of the Liver Transplant Program, (FMRP-USP), Brazil.

\begin{abstract}
Chronic liver disease is a considerable burden on society, being one of the three main causes of death in certain regions of Africa and Asia. Liver transplant is the only treatment option for cirrhosis, which is the end stage of many chronic liver diseases. This article reviews the preventable causes of cirrhosis and the preventive strategies which could be implemented in order to avoid the catastrophic consequences of cirrhosis. With small variations around the world, 70 to $80 \%$ of the end stage liver diseases are caused by excessive alcohol consumption and by viral hepatitis, both of which are potentially preventable. Excessive alcohol consumption has important public health consequences because of its involvement not only with cirrhosis, but also with motor vehicle accidents, unemployment, domestic violence etc. Among the viral causes, Hepatitis Virus B and C have the greatest impact on public health. Effective vaccine is available for Hepatitis Virus B and must be put in use. While a vaccine for Hepatitis Virus $\mathrm{C}$ is awaited, effective preventive strategies should be undertaken to avoid the preventable cases of end stage liver disease.
\end{abstract}

Key words: Liver Transplantation. Hepatitis Virus B. Hepatitis Virus C. Chronic Hepatitis.

\section{RESUMO}

As doenças hepáticas crônicas estão entre as três principais causas de morte na África e Ásia.O transplante de fígado é o único tratamento curativo para esta doença hepática de caráter terminal.O presente artigo tem como objetivo apresentar as causas passíveis de prevenção de cirrose e as estratégias que podem ser utilizadas no sentido de preveni-las. Com pequenas variações ao redor do mundo, 70 a $80 \%$ das doenças hepáticas terminais são causadas por consumo excessivo de álcool e por hepatites virais que são doenças passíveis de prevenção.O consumo excessivo de álcool é importante problema de saúde pública, pois envolve violência doméstica, acidentes de trânsito, além da possível evolução para cirrose e suas conseqüências. Entre as causas virais as hepatites pelo vírus B e C têm o maior impacto na saúde pública. Para a hepatite B já há vacinas disponíveis. Enquanto a vacina para a hepatite C é ainda aguardada, estratégias efetivas de prevenção devem ser efetuadas com o objetivo precípuo de se evitar, por conseqüência, casos de hepatopatias crônicas desta natureza.

Descritores: Cirrose Hepática. Hepatites Virais. Hepatite B. Hepatite C. Hepatite Crônica. Prevenção.

\section{Introduction}

Taking into account the public health, economic and social viewpoints, chronic liver disease (CLD) represent a great problem for a majority of the world as it leads to an increase in morbidity and mortality, considerable absenteeism and high cost in the treatment of related disorders. It represents the tenth cause of death in the United States, with about 25 thousand annual deaths ${ }^{1}$, and it is among the three leading causes of death in the African and Asian continents. Chronic liver disease comprises of a number of conditions of different etiologies, characterized by a continuum, right from hepatitis to frank hepatic cirrhosis. This latter condition represents the largest fraction of CLD, being secondary, in most cases, to chronic use of alcohol (60 to 70\%) and to viral hepatitis $(10 \%)^{2}$. Once the physiopathological process of the disease is installed, the only cure is liver transplantation, an extreme situation which has in cirrhosis about $70 \%$ to $90 \%$ of its indications ${ }^{3}$. At the Hospital das Clínicas da Faculdade de Medicina de Ribeirão Preto da Universidade de São Paulo, 68\% of the 
patients waitlisted for liver transplantation developed end-stage liver disease due to potentially avoidable causes, alcohol and viral hepatitis (personal communication). Chronic alcohol consumption is directly related to liver damage, increasing the incidence of both cirrhosis and hepatocellular carcinoma (CHC). Around 90 to $100 \%$ of high risk alcohol consumers will have hepatic esteatosis, 10 to $35 \%$ will develop hepatitis and between 8 to $20 \%$ will evolve to hepatic cirrhosis. ${ }^{4}$ According to national data, hepatic cirrhosis in men accounts for almost half the cases of mortality related to gastrointestinal diseases..$^{5}$ These revealing figures are due to a high alcohol per capita consumption, illustrated by an increase of about $100 \%$ in beer sales between 1985 and 1995. In the last year, Brazilians have consumed around 7.5 billion liters of beer, which represented an average of 45 liters per capita. ${ }^{6}$ It is known that the daily consumption of 4 or more doses of alcohol increases the risk of cirrhosis and death ${ }^{1}$, where abstinence is the only way to prevent the progression of the liver disease to cirrhosis. The objective of this paper is to review the preventive strategies available to avoid the most common causes of chronic liver disease, which lead to the indication of liver transplantation.

\section{Viral Hepatitis}

Of the set of viral hepatitis that affect the human beings, those that cause the greatest impact on the public health are the infections caused by viruses B and C, because in addition to having an ample geographic distribution in the world and infecting an alarming number of individuals, chronification of the disease is relatively frequent, which in turn is associated with the development of cirrhosis and CLD. ${ }^{7}$

\section{Virus $B$}

Estimates of hepatitis distribution all over the world must be seen with certain reserve, as there are no studies of prevalence with a worldwide coverage and there is a considerable under notification of cases, especially in developing countries, which show varied degrees of deficiencies in their epidemiological surveillance systems. Therefore, forecasts of the distribution of these diseases are most of the time based on cross-sectional studies, usually involving segments of the society that are not representative of the whole population, such as blood donors, CLD carriers, sex professionals, health professionals, etc. Despite these limitations, the World Health Organization (WHO) estimates that about two billion people, in the world, have already been infected by the hepatitis B virus (HBV), out of whom approximately 350 million have developed chronic infection, with a marked increase in the risk of developing hepatic cirrhosis and $\mathrm{CHC}$. The estimated annual mortality ranges from 500 thousand to 1.2 million, out of which 320 thousand are caused by CLD. In our country, even though with considerable regional variations, the Health Ministry estimates that $15 \%$ the population are infected, and among these, $1 \%$ are carriers of the chronic form of the disease. ${ }^{9}$ In spite of the existence of effective vaccination since the early 1980s and several reports of successful experiences of diminution of incidence of acute cases and chronic forms of the disease, hepatitis B remains an important public health problem worldwide, due to the large number of individuals infected prior to the advent of immunization programs ${ }^{10,11}$ and also because it is strongly related to poor social conditions, which is prevalent in large global areas. In the last two decades, the development of anti-viral drugs such as alpha interferon, the lamivudine and, more recently, pegylated interferon, adefovir dipivoxil and entecavir, brings a light of hope for the chronically infected subjects. However, factors such as high costs, relevant side-effects and the development of various degrees of viral resistance limits the effectiveness of these measures ${ }^{12}$, a fact that reinforces the importance of considering primary prevention a priority.

\section{Primary Prevention Strategies for Hepatitis Virus B}

The main strategy for the primary prevention of hepatitis B and, consequently, the CLD related to it, is the inclusion of the specific vaccine in the immunization programs of every country. It is an extremely safe and effective immunobiological medication developed by genetic engineering, which attains serum conversion rates in the order of $95 \%$ when it is correctly applied in the recommended scheme of 3 doses, with one-month intervals, between the $1^{\text {st }}$ and the $2^{\text {nd }}$, and 5 months, between the $2^{\text {nd }}$ and the $3^{\text {rd }}$ dose. Because of its confirmed effectiveness, and taking into account the strong association between chronic $\mathrm{B}$ hepatitis and primary liver hepatocarcinoma, the vaccine is considered as a preventive measure against this form of malignant liver tumor. Recently, several countries have chosen to direct the vaccination to priority risk groups, among which we have the health professionals who work in contact with blood, sex professionals, those who are in contact with infected individuals, haemodialysis patients and male homosexuals. Although this strategy is consistent with the knowledge available about the natural history of $B$ hepatitis, a reason why these groups must be remain a permanent target of vaccination, nowadays there is practically a consensus that the vaccine should be included in the routine schedule, as early as in the first year of life, so that it progressively produces pools of immunized individuals who will block the viral circulation in the population. Concomitantly we should also try to vaccinate adolescents, to simultaneously cover a group at high risk for sexual transmission and accelerate the formation of protected pools. This is the mainstream of the control program implemented in Brazil that addresses as a vaccine target the subjects up to the age 20 years. Another effective way to bar the transmission of the virus is the prevention of perinatal infection, by including HbsAg screening in the pre-natal follow-up program. The babies born to seropositive mothers should receive adequate protection, which consists of both the specific hyper-immune immunoglobulin and the $1^{\text {st }}$ vaccine dose, preferably in the first 12 hours after birth. Since around 
$90 \%$ of those who acquire virus B during early infancy develop the chronic form of the disorder, the importance of this preventive strategy becomes evident, particularly in the regions where the HBV vertical transmission rate is high. However, it should be kept in mind that the simple implementation of a routine test is no guarantee of the quality of assistance given to neonates of $\mathrm{HBs} \mathrm{Ag}+$ mothers, as it has been shown in a recent evaluation carried out in the city of Ribeirão Preto. This study detected inadequate care in $1 / 3$ of the deliveries of mothers with chronic HBV infection ${ }^{13}$. No less important is the adoption of individual preventive measures for the health care providers in order to avoid the nosocomial transmission of $B$ virus from patients, by means of proper preventive practices such as the use of gloves, the avoidance of recapping needles and the use of adequate containers for the disposal of piercing and cutting material. Screening of blood and blood products through of HbsAg should also be instituted ${ }^{14}$. Finally, the potential for sexual transmission stresses the importance of another primary preventive measure, which is the use of condoms during intercourse with unknown or infected partners.

\section{Virus $C$}

Hepatic infection by virus $\mathrm{C}(\mathrm{HCV})$ was identified more than two decades ago and its complications account for some of the most serious public health problems in the contemporary world, as the percentage of patient who develop chronic infection reach figures of around $50 \%$ to $80 \%$ of those who have been infected. Recent estimates of the $\mathrm{WHO}^{15}$ state that around $2 \%$ of the world population, which accounts for approximately 123 million people, are chronically infected by virus C. In the United States, it is the main determinant of CLD and the main reason for the indication of liver transplantation ${ }^{16}$. Contact with contaminated blood and needles/syringes is an important mode of VHC transmission, which explains the high incidence seen nowadays among the users of illicit intravenous drugs, as well as the elevated number of people who have been infected through blood transfusions undertaken until the early 1990s, when the lack of knowledge of the virus prevented its detection among the blood donors. Similar to the virus B, it also has a worldwide distribution with prevalence rates of great variability among the different countries, with a predominance in the African and Asian continents. In Brazil, WHO estimates prevalence rates between $2.5 \%$ to $4.9 \%{ }^{17}$. The significance of the impact, both current and future, on public health, of VHC and its complications, becomes evident when we analyze the recent world trend of increasing mortality due to CLD and CHC attributed to $\mathrm{VHC}^{11,15}$. Considering that the natural history of hepatitis $\mathrm{C}$ includes a long asymptomatic period, and because of this, a great number of people entirely ignore their problem, we expect a marked increase in the number of cases with complications related to this virus during the next decades, causing great financial strain on the health systems of several nations.

\section{Primary Prevention Strategies for Hepatitis Virus $C$}

Contrary to the HBV, there still does not exist a vaccine capable of blocking the transmission of $\mathrm{HCV}$, mainly because of the several genotypes and the continuous appearance of mutations, similar to what happens with the HIV ${ }^{18}$. Also, there are no effective postexposure prophylactic measures, turning the adoption of preventive strategies the only means to diminish the risk of contact with the HCV. Such strategies must include, on a priority basis, the highest risk groups, among them the users of illicit intravenous drugs. As a rule, these groups are difficult to reach, requiring a special effort from the public health services in order to identify them, win their confidence, and work together to develop greater awareness, in addition to the efforts of minimizing the damage caused by offering periodic exchange of syringes and needles. Care in the blood bank services, such as the ruling out of potential donors with high risk backgrounds and careful serological screening for $\mathrm{VHC}$, are mandatory measures in order to avoid transmission. Equally relevant are the individual measures, such as safe handling practices of biological material, in order to reduce accidental exposure of health care professionals 19 . Although controversial, only a small percentage of the spread seems to be due to sexual transmission, but it increases proportionally with the multiplicity of partners and to the adoption of risky sexual practices. Therefore, sex professionals deserve the attention of the health services in order to promote awareness and encourage the use of condoms. As a last commentary on the prevention of types $\mathrm{B}$ and $\mathrm{C}$ viral hepatitis, their transmission mechanisms are very similar to those of the HIV, therefore the preventive efforts related to these three viruses should be coordinated, as the Brazilian Health Ministry has been trying in the recent years.

\section{Alcoholism}

According to WHO's data, public health problems related to alcohol usage has reached alarming proportions, its consumption being one of the most important public health risk factors of the world ${ }^{20}$. Estimates are that it accounts for about 1.8 million annual deaths, which corresponded to $3.2 \%$ of death records in 2000. In developing countries, $9.2 \%$ of years lost due to handicaps associated to neuropsychiatric disturbances and accidents are considered secondary to alcohol consumption ${ }^{20}$. Excessive consumption causes economic and social damages not only to its users, but also to all those who live with them. These damages include physical injuries, accidents, prolonged absenteeism and premature deaths, especially among motor vehicle drivers and pedestrians who are victims of car accidents. In 2001, according to the data from the Ministry of Health (DATASUS), there were 84,467 hospital admissions for treatment of disorders related to alcohol usage, a figure which is four times higher than that for the rest of the other drugs. The average hospital stay was of 27.3 days, generating an annual cost of more than $\mathrm{R} \$ 60$ million for 
the national public health care system (SUS) ${ }^{21}$. During 2004 , in the state of São Paulo, SUS paid for more than 2000 hospital admissions, where the leading diagnosis was alcoholic hepatic cirrhosis, leading to a cost of more than R\$2.7 million, with an average of $\mathrm{R} \$ 1,366.78$ per admission $^{22}$. These numbers do not include the expenses with outpatient care or diseases secondary to alcohol that involve other organs and systems. SUS is responsible for the financing of $92 \%$ of all liver transplantations carried out in Brazil ${ }^{23}$. The Hospital das Clínicas da Faculdade de Medicina de Ribeirão Preto, São Paulo University, was reinbursed in a one-year period (2004/2005), in the value of R\$337,519.19 for the liver transplants undertaken. According to information from the Costs Department of this hospital, the cost of each procedure varied from $\mathrm{R} \$ 11,080.15$ to $\mathrm{R} \$ 83.041 .55$, depending on the presence or not of co-morbidities and on pre- or post-operative complications. In the United States, between 1992 and 2001, 41,734 liver transplantations were carried out. Of these, $12.5 \%$ were due to CLD secondary to alcohol consumption, the second most common indication for liver transplantation. Inspite of the considerable number of transplants performed, in 2002, 17,646 patients were still waiting for liver grafts. In this list, $14.1 \%$ of patients had CLD secondary to alcohol and infection by hepatitis $\mathrm{C}$ virus ${ }^{4}$. According to data from the National Transplantation System of the Health Ministry, there are more than 7,000 people waiting for a liver transplantation in Brazil, of which more than $50 \%$ are in the waiting list of the state of São Paulo ${ }^{23}$.

\section{Prevention Strategies Against Alcoholism}

Due to the magnitude of the problem, it is crucial to adopt preventive measures, aimed to achieve two main objectives: (i) to reduce alcohol consumption in the general population and (ii) to conduct a screening program in order to identify early those individuals who consume alcoholic beverages excessively, before they develop serious complications such as CLD. These two objectives are respectively the primary and secondary preventive measures.

\section{Primary Prevention against Alcoholism}

Primary prevention has as its aim the reduction of alcohol consumption by the population through the use of different strategies. One possible measure is to reduce the availability ${ }^{20,24,25}$. Some public policies have been implemented; for instance the prohibition of alcoholic beverages in certain places, such as pubs and restaurants near the highways. Similarly, there is the law which prohibits the sale of alcoholic beverages to minors, with harsh penalties to the owners of those shops which do not abide by this law. The policy of higher taxes on alcoholic beverages is another means for primary prevention, by increasing the net price and making it difficult to acquire the product. It is already known that the cheaper the product is, the more accessible it becomes and consequently the number of consumers also increase. This situation is clearly illustrated by the aguardente (spirits), with an annual production rate of 1 billion liters in Brazil, and that, in its more popular versions, is sold at an average price of US\$ 1.5 a bottle, one of the cheapest of the world. It is estimatet that a $100 \%$ price raise may cause a consumption reduction of $30 \%$, which shows the potential this measure has to reduce consumption of alcoholic beverages ${ }^{25}$. Still in primary prevention, educational programs targetted at the community should be undertaken, addressing school students, adolescents, pregnant women, drivers, etc $20,21,24,26,27$. Information regarding health have a stronger impact if they are associated with campaigns in the media, with information about the toxic effects of the beverages and its physical and social outcomes.

\section{Secondary Prevention}

Secondary prevention has as its aim the early diagnosis of excessive alcohol consumption, even before they show any signs and symptoms. Professionals who work in Primary Care are in a favorable position to identify and intervene, because they act in the first level of health care, where they establish the first contact with the users of the health system. Furthermore, these professionals have the chance to maintain a long-term follow-up of their patients, which facilitates an earlier and more effective approach. Taking into consideration that most of the population seek a medical service at least once a year, health professionals have several chances to investigate alcohol abuse by their patients, being able to intervene as soon as they detect suspicious signs 24,28 . Active search for cases is highly recommended due both to the marked prevalence of alcoholism and to its potentially adverse effects. Incorporating screening strategies in the day-to-day life of health professionals, whether doctors, nurses or dentists, turns possible the evaluation of alcohol consumption, and therefore identify drinkers at risk. Several studies reveal that the measurement of consumption, by means of questionnaires or semi-structured interviews is useful as a guide to health professionals during their clinical care of the users. The most commonly used tools are CAGE, Michigan Alcoholism Screening Test (MAST) and The Alcohol Use Disorders Identification Test (AUDIT), which show sensibility and specificity acceptable values ${ }^{25,27}$. There is enough evidences confirming the fact that both screening and counseling are effective in reducing alcohol consumption and related disorders, especially in setting where there is a closer relationship between users and professionals ${ }^{27}$.

\section{Final considerations}

Cirrhosis is the final result of a variety of etiologies which cause hepatocellular damage, which include toxins (for example alcohol) and virus (for example hepatitis virus $B$ and $C$ ). Although the mechanisms vary, the pathological response is uniform: hepatocellular necrosis followed by fibrosis and nodular regeneration. Studies involving autopsies suggest that the incidence of 
cirrhosis is between 3.5 and $5 \%$. Inspite of this incidence, more than half the cases of cirrhosis are preventable. Since the beginning of the 1980's, the surgical treatment of CLD through liver transplantation has obtained favorable results with greater than $70 \%$ long-term survival - Although liver transplantation is available, the complexity of the procedure and the lack of donors makes this option inaccessible to most. Therefore, for the effective resolution of the situation, it is extremely important not only to stimulate cadaveric donation and maintain transplant centers according to the needs, but also implement measures to reduce the number of patients who develop CLD. The need for preventive measures (Chart1) is highlighted by the fact that most of the patients awaiting liver transplants, developed CLD due to preventable causes.

CHART 1 - Strategies for the prevention of Chronic Liver Diseases

Screening

Antenatal HbsAg testing

Screening of blood donors - viral hepatitis

Primary care screening for excessive alcohol

Preventive measures

Hepatitis B

Include $\mathrm{HBV}$ vaccine in the vaccination calender

Prevent the perinatal vertical transmission using immunoglobulin

Vaccinate high risk groups (young adults, health care workers, sex professionals)

General measures

Cautious utilization of hepatotoxic medication

Health care workers: proper use of protective gear and training to avoid perforating accidents

Educational campaigns on the effects of alcohol and drugs

Public policies for the reduction of alcohol consumption

\section{References}

1. Riley TR 3rd, Bhatti AM.. Preventive Strategies in Chronic Liver Disease: Part I. Alcohol, Vaccines, Toxic Medications and Supplements, Diet and Exercise. Am Fam Physician. 2001;64(9):1555-60.

2. Crawford JM. The Liver and the Biliary Tract. In: Cotran RS, Kumar V, Robbins SL. Robbins Pathologic Basis of Disease. 5ed. Philadelphia: W. B. Saunders Company; 1994. p.831-96.

3. Castro-e-Silva Junior O, Sankarankutty AK, Oliveira GR, Pacheco E, Ramalho FS, Dal Sasso K, Tolentino E, Mente ED; França AVC; Martinelli ALC. Transplante de fígado: indicação e sobrevida. Acta Cir Bras. 2002;17 Suppl 3:S83-91.

4. Anantharaju A, Thiel, DHV. Liver transplantation for alcoholic liver disease. Alcohol Res Health. 2003;27:257-68.

5. Lessa I. Cirrhosis of the liver in Brazil: mortality and productive years of life lost prematurely. Rev Panam Salud Publica. 1997;1:125-32.

6. Cotrim BC. Country profile on alcohol in Brazil. Alcohol Res Health. 2003;27(3):1-186.

7. Passos ADC. Aspectos epidemiológicos das hepatites virais. Medicina (Ribeirão Preto). 2003;36:30-6.
8. World Health Organization [homepage on the Internet]. Geneva: The Organization; c2006 [updated 2000 Oct; cited 2006 Mar 13]. Hepatitis B. Fact Sheet no. 204; [about 2 screens]. Available from: http://www.who.int/ mediacentre/factsheets/fs204/en/

9. Ferreira CT, Silveira TR. Hepatites Virais: aspectos da epidemiologia e da prevenção. Rev Bras Epidemiol. 2004;7:473-87.

10. Lavanchy D. Worldwide epidemiology of HBV infection, disease burden, and vaccine prevention. J Clin Virol. 2005;34 Suppl 1:S1-3.

11. El-Serag HB, Mason AC. Rising incidence of hepatocellular carcinoma in the United States. N Engl J Med. 1999; 340:745-50.

12. Hoofnagle JH. Hepatitis B- Preventable and Now Treatable. N Engl J Med. 2006; 354:1074-6.

13. Perim EB, Passos ADC. Hepatite B em gestantes atendidas pelo Programa do Pré-Natal da Secretaria Municipal de Saúde de Ribeirão Preto, Brasil: prevalência da infecção e cuidados prestados aos recém-nascidos. Rev Bras Epidemiol. 2005; 8:272-81.

14. Mast EE, Alter MJ, Margolis HS. Strategies to prevent and control hepatitis $\mathrm{B}$ and $\mathrm{C}$ virus infections: a global perspective. Vaccine. 1999; 17:1730-3. 
15. Shepard CW, Finelli L, Alter MJ. Global epidemiology of hepatitis c virus infection. Lancet Infect Dis. 2005; 5:558-67.

16. Focaccia R, Baraldo DCOM, Souza FV. Epidemiologia. In: Focaccia, R. Tratado de Hepatites Virais. São Paulo: Atheneu; 2003. p.221-9.

17. World Health Organization. Hepatitis C: global prevalence (update). Wkly Epidemiol Rec. 2000;75:17-28.

18. World Health Organization [homepage on the Internet]. Geneva: The Organization; c2006 [cited 2006 Mar 13]. Viral Cancers. Hepaties C; [about 5 screens]. Available from: http://www.who.int/vaccine research/diseases/ viral cancers/en/index 2 .html.

19. Centers for Disease Control and Prevention. Recommendations for Prevention and Control of Hepatitis C Virus (HCV) Infection and HCV-Related Chronic Disease. MMWR Recomm Rep. 1998; 47(RR19):1-39.

20. Organización Mundial de la Salud [database on the Internet]. Problemas de salud pública causados por el uso nocivo del alcohol. In: $58^{\circ}$ Asamblea Mundial de La Salud, 2005, Genebra. p.1-4. c2006 - [cited 2006 Mar 22]. Available from: http://www.who.int/substance_abuse/ report by secretariat who 58publichealth problems alcohol spanish.pdf

21. Ministério da Saúde. A Política do Ministério da Saúde para a atenção integral a usuários de álcool e outras drogas. 2ed. Brasília; 2004. p.1-60.

22. Ministério da Saúde [database on the Internet]. Sistema de Informações Hospitalares - Autorização de Internações Hospitalares. Internações em 2004 com diagnóstico principal de Cirrose Hepática Alcoólica. Brasília: Ministério da Saúde, 2004. c2006 - [cited 2006 Mar 31]. Available from: http://www.datasus.gov.br
23. Secretaria Estadual da Saúde do Estado de São Paulo [database on the Internet]. Transplantes segundo a fonte pagadora - Fígado. c2006 - [cited 2006 Apr 12]. Available from: http://www.saude.sp.gov.br/portal/ 74b29e53c89b06a7005976c2acab6571.htm

24. Garcia RC. Abuso de Alcohol. In: Brotons C, Ciruano R, Iglesias M. Manual de prevención en Atención Primaria. Barcelona: Casanova; 2003. p.67-80.

25. Associação Brasileira de Estudos do Álcool e outras Drogas [homepage on the Internet]. Porto Alegre: Associação; c2006 [cited 2006 Mar 22]. Laranjeira R. Políticas de Ação Governamental. Legalização de drogas no Brasil: Em busca da racionalidade perdida; [about 7 screens]. Available from: http://www.abead.com.br/políticas

26. Ministério da Saúde. Inquérito domiciliar sobre comportamentos de risco e morbidade referida de doenças e agravos não transmissíveis: Brasil, 15 capitais e Distrito Federal, 2002-2003. Rio de Janeiro: INCA; 2004.p111-20.

27. Canadian Task Force on Preventive Health Care [homepage on the Internet]. Ontario: The organization; c2000 [cited 2006 Mar 21]. Early Detection and Counselling of Problem Drinking; [about 8 screens]. Available from: http://www.ctfphc.org/ Full Text printable/Ch42full.htm

28. Babor, T.F., Higgins-Biddle, J.C. Intervención Breve. Para el consumo de riesgo y perjudicial de alcohol. Um manual para la utilización en Atención Primaria. Organización Mundial de La Salud; 2001: p.1-52.

29. Layton F Rikkers. Surgical Complications of Cirrhosis and Portal Hypertension. In: Townsend: Sabiston Textbook of Surgery, $17^{\text {th }}$ Edition, Philadelphia, WB Saunders, 2004.

\section{Correspondence:}

Orlando de Castro e Silva Jr.

Rua Campos Salles, 809 - $9^{\circ}$ andar. CEP: 14015-110

Centro, Ribeirão Preto - SP - Brazil.

Email: orlando@,fmrp.usp.br
Conflict of interest: none

Financial source: CNPq and FAPESP

\section{How to cite this article:}

Silva SA, Santos LL, Passos ADC, Sankarankutty AK, Martinelli ALC, Castro e Silva O. Chronic liver disease prevention strategies and liver transplantation. Acta Cir Bras. [serial on the Internet] 2006;21 Suppl 1. Available from URL: http://www.scielo.br/acb 